\title{
クロレラエキスの細胞分裂促進作用 \\ Promotive Effect of Chlorella Extract \\ on Cell Division of Microorganisms
}

（昭 和 41 年 12 月 12 日受理）

\section{西土井睦 \\ (Mutsumi Nishidoi)}

In the previous studies, it was reported that Chlorella extract contained growth promoting substance for microorganisms.

Several experiments have been carried out with Tetrahymena pyriformis-W and Saccharomyces cerevisiae.

It is concluded that, 1) growth-promotion is accomplished chiefly by increasing of cell number rather than enlargement of cell size, and 2) promoting effect of chlorella extract is superior to that of yeast extract.

Both extracts were fractionated by Sephadex G-25, and a fraction specific in Chlorella extract was found to be the most effective in growth of microorganisms.

\section{まえがき}

クロレラは単細胞の粶藻類の一種であって蛋白質含有 量が高く(約 50\%), しかも良質 (アミノ酸バランスが 良い)であることから食糧(主として蛋白源)，飼料抽よ び宇宙旅行での食糧, ガス交換体としての利用研究が進 められている。飼料に数パーセント混合して動物実験が なされた結果から, 現在ではクロレラは単に食䊓源, 蛋 白源としてでなく，動物の成長を促進させる効果を持つ るのとして利用されてきている。筆者らは，その成長促 進効果はクロレラ中の微量成分に基因寸るとの観点か ら，それを抽出したクロレラエキンの成長促進効果を原 生動物（テトラヒメナ）を用いて研究した。一般には類 似の組成を有するるのと考えられているイーストエキス と効果の比較を検討した。

\section{実験材料と方法}

1) 原生動物 : Tetrahymena Pyriformis-W

2）培 地: $3 \%$ ペプトン水

3）培養方法: $30^{\circ} \mathrm{C}, 2 \sim 3$ 日 静置培養

4) エキス添加濃度：イーストェキス (Y.E.), クロレ ラエキス(C.E.), とすに紫外吸光 $260 \mathrm{~m} \mu て ゙$ 調整添加した。

5 ) 成長量湘定 :

a) 細胞数 (Cell number =C. N.), トーマ寒天平板 法 b) 乾燥重量 (Dry weight $=$ D. W.), 遠沈, 水洗 後, $105^{\circ} \mathrm{C}$ 乾燥, 恒量

c) 充媜細胞容積 (Packed cell volume =P.C. V.)

6）分子分画 : Sephadex G-25, 溶離液は蒸留水

C. E., Y. E. ともに $10 \mathrm{~g} / 1$ に溶解, 吸着させる。

\section{実験結果と考察}

1） C. E.と Y. E. の紫外吸光スペクトル

クロレラエキス (C.E.) とイーストエキスは一般分析 では組成的にほとんど差は認められないとの観点から， 同一乾燥重量の水溶液を作り, その紫外吸光スペクトル を測定した結果を図 1 に示す。

因 1.C.E., Y.E.のUV 吸収スペクトル

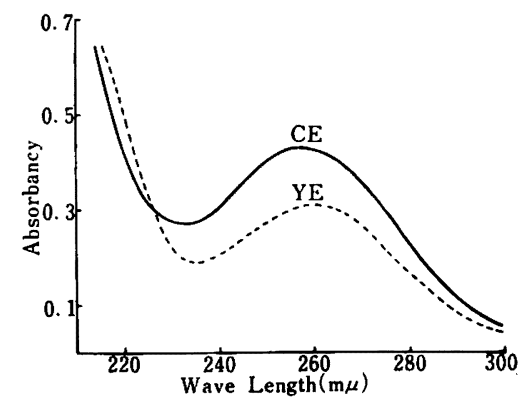

この四から C. E. には $235 \mathrm{~m} \mu$ に函少, $260 \mathrm{~m} \mu$ に 極大值があり，核酸関連物質を含んでいることが解っ た。Y.E. あほ浔同一のパターンを示すが，核酸関連物 
質の含有量は C.E.より少ない。C. E. 中の含有量を 1 とすると 0.65 に相当する。

2） C.E. と Y.E. の成長促進効果
ペプトン培地（3\%ペプトン氷溶液）に C. E. および Y.E. を添加し, $30^{\circ} \mathrm{C} て ゙ 3$ 日培養した場合の C.N., D. W. および P.C.V. の結果を四 2 に示す。C.E. および

因 2. C.E., Y.E. の成長効果

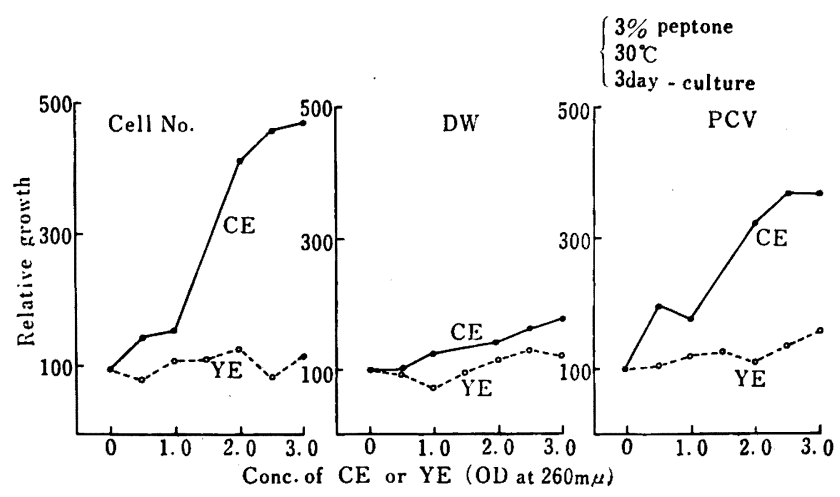

Y.E. の添加濃度は $260 \mathrm{~m} \mu$ の吸光度て調整した。C.E. Y.E.での結果を図 4 に示す。 の添加量を堌せば，ほほ比例的に成長促進効果が認めら れるに反して，Y.E. は添加してもほとんど効果はな い。C.E. の效果 D D.W. に比較して C.N. と P.C.V. に効果が影著であることが特徵である。この結果から C.E. の成長促進効果は細胞分裂を促進させる機構に作 用しているすのと考える。C.N. と'P.C.V. とが異常に 增加するにすかかわらず, D.W. があまり增加しなかっ たのは現培地では細胞数に適合した栄養分がなかったこ とに原因がある。

3） C.E. および Y.E. の分子分画

柴外吸収パターンに大差がないにすかかわらず，成長 促進效果に顕著な効果の差が認められる原因を究明する ために Sephadex G-25 (分子節)を用いて, 両エキス の分子分画を行なった。C.E. でのパターンを図 $3 に$ ，
図3. C.E. の Elution Pattern

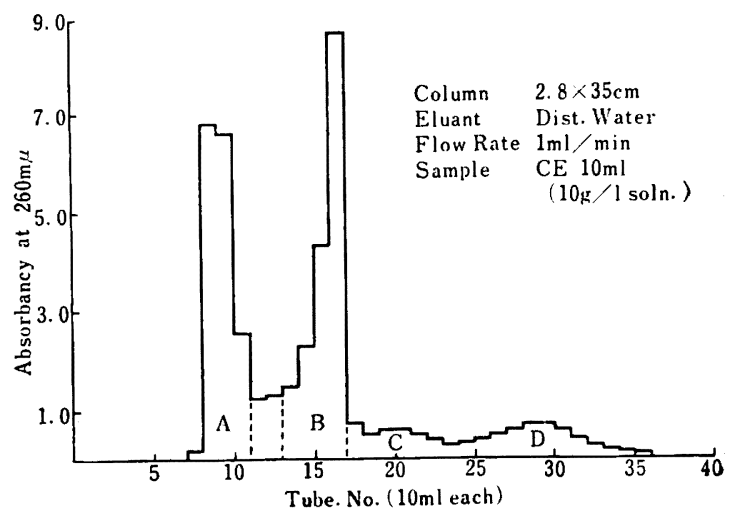

因 4. Y.E. の Elution Pattern

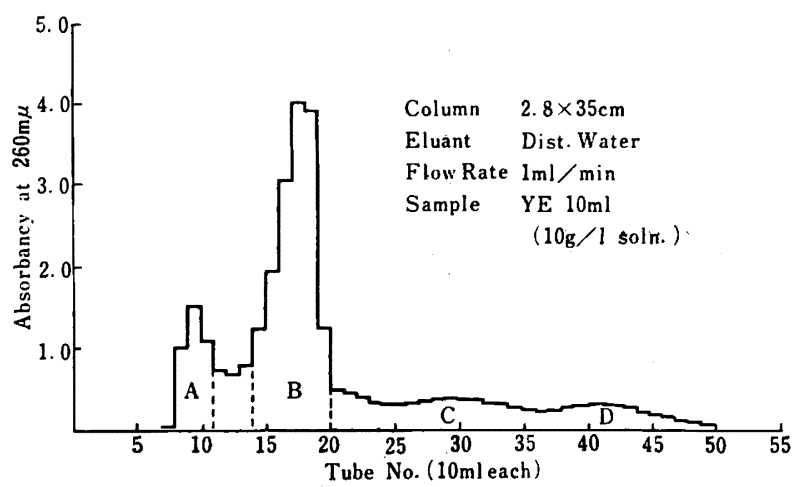


C. E. にはA フラクションがBフラクショ ンとほほ同じくあるが, Y. E. ではAフラク

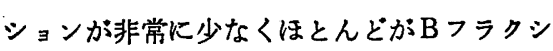
、ンであった。

4）分画 $\mathrm{A}$ お。び $\mathrm{B}$ の成長促進效果

C.E. および Y.E. のフラクションAによ るテトラヒメナの成長とエキス添加量との関 孫を図 5 に, フラクションBでの結果を図 6 に示す。C.E. の効果は分画前と同じく, 細 胞数では 7 倍, P.C.V. では 4.5 倍と成長促 進効果をるたらし, 比較的効果の薄かった D.W. にも5 倍の促進効果をすたらしている ことが特色である。Y.E. は全く成長促進効 果を持たないことが解った。

フラクション B の効果は分画前と傾向が類 似して括り，C. E. の効果は分画Aがより効 果を有して找り，Y.E. の効果は主として分 画Bによるすのであることが解った。分画前 と分画後の両結果から C. E. と Y. E. とは 異質のものであると断定できる。核酸関連物 質の濃度でエキス添加量を調整しており，全 乾燥エキス中の核酸含有量もY.E. が少な い(図1参照) ので, 両エキスの添加量を乾 燥重量で調整すると成長促進の効果の差はよ り顕著になる。

一般分析（栄養分析）によっては差のない 両エキスる，実際にはその本質に打いて非常に異なって いるということが解った。クロレラる暗培養すると細胞 分裂促進効果が低い実駼結果から，暗培盖ではイースト 的なクロレラができることが解る。明培盖をすることに よってクロレラに特有の微量成分が合成されることが解 った。

5）クロレラエキスと S-H 代謝

細胞分裂に際しては細胞内の S-H 基が非常に重要な 役割を演ずることが知られているので，C.E.のS-H 代 謝におよほ影響について検討した。 S-H 代謝を阻害 する薬品の代表的なものとして $\mathrm{Cu}^{+2}$ と $\mathrm{Se}^{+2}$ を取り， C. E. を添加することによって阻害效果が抑制されるか どうかについて検討した結果を図7に示す。

$\mathrm{Cu}^{+2}$ は C.E. なしでは阻害的に働くが, C. E. が共存 すると $10^{-3} \mathrm{M}$ 以上の濃度では阻害的に $10^{-4} \mathrm{M}$ 以下の 濃度ではほとんど阻害効果を示さなくなることが解っ た。

$\mathrm{Se}^{+2}$ のもつ阻害效果は非常に著しいが，やはり C.E. が共存することによって阻害効果は减少してくる。その 阻害减少率す C.E. の共存灌度に比例していることが解
因 5. Fraction A の成長效果

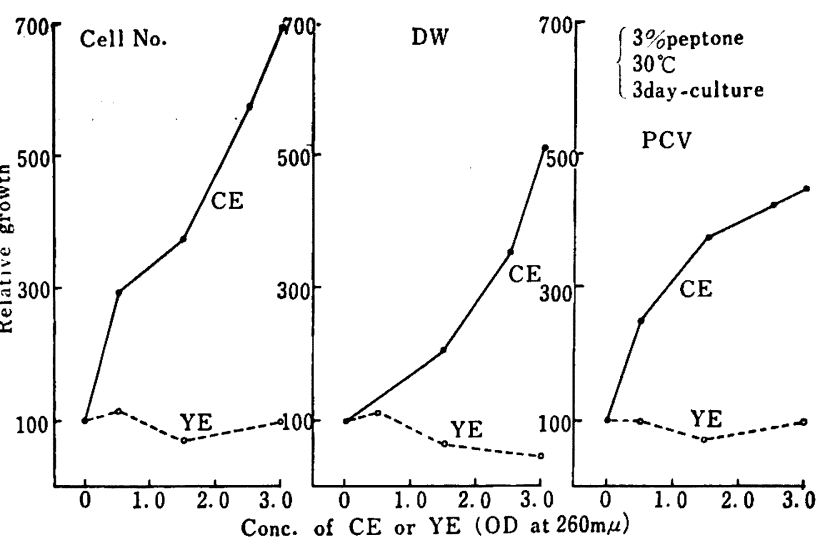

因6. Fraction B の成長効果

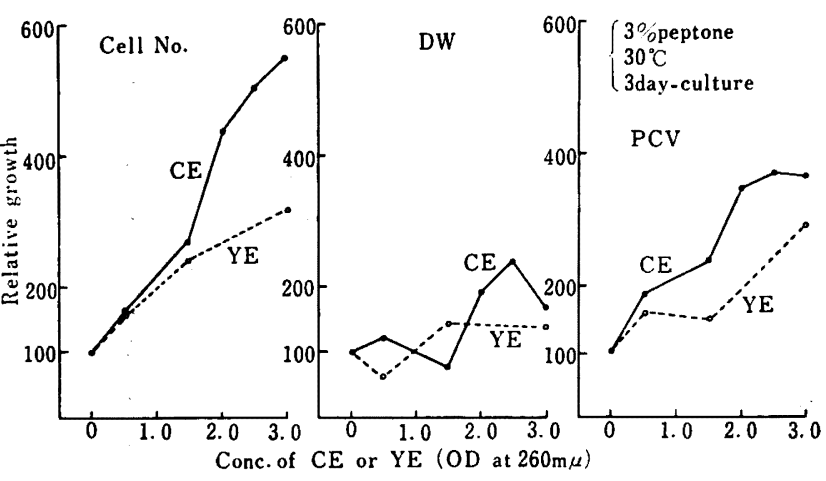

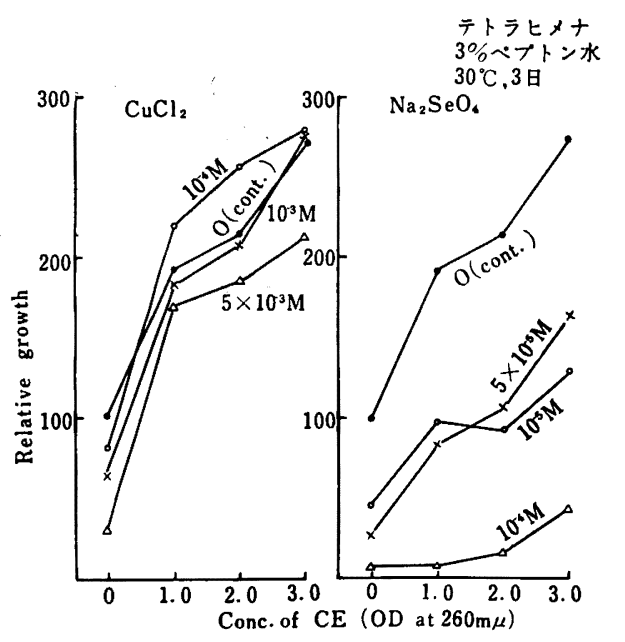

った。

以上の実験結果から C. E. は細胞分裂を支配する S-H 代謝に十分作用していることが解り，細胞分裂の機構に 
作用するすのであることが推湘できる。

$$
\text { まとめ }
$$

食䊓源, 蛋白源として, また光合成の媒体として研究 されてきたクロレラには成長促進物質が含まれているこ とが解った。その物質は一般分析ではとんどイースト エキスに類似しているが，その生物学的効果において非 常に異なっていることが解った。

その有効物質は光合成を行ならことによって生産され るすのであって,クロレラであっても暗培養したすので は非常に少ないことが解った。

成長促進効果す細胞分裂を促進させることに特徵があ る。しかし培地が分裂速度に適していないことに原因か あるようで，培地組成さえ検討すれば全重量す細胞数の 增大に比例して增加するすのである。

クロレラエキスとイーストエキスは化学分析（現状 の）では区別できないか，分子篩によって簡単に分別で
き，しかも効果の差が明確にし得ることが解った。

あらゆる生物が生細胞の集団で，かつ細胞の分裂によ って生命を維持していることから考えると，クロレラエ キスはあらゆる生命の根源を与えてくれるすのであると いえる。

人間を含めた高等動物に対して成長促進効果が認めら れているが，それは単にクロレラの蛋白質量です必須つ ミノ酸のバランスだけでもなく，むしろ細胞分裂が促進 されることにあるのではあるまいか。したがってクロレ ラたけけで全栄養を吸収する必要はなく，むしろ栄養価 （カロリーではない）を高める効果を利用すべきであ る。最近のクロレラは，単に蛋白源としてだけ注目され ているのではなくなった。

クロレラの消化率が論議されていたが, むしろ変敗に よることが多かったが, 現在では研究, 培養および処理 技術が発達して来たので变敗などははとんど考えられな い。

（クロレラ工業株式会社開発部）

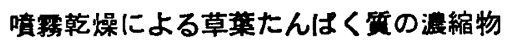

アルファルファおよびェンドウ豆の茎葉の计液を噴祴 乾燥して草葉たんぱく質の濃縮物を作った。この濃縮物 は原材料がアルファルファの場合，たんぱく質 30\% 以 上, せんい $1 \%$ 以下であるので, 非反すう獣の飼料に用 いられる。これをさらに95\%エタノールで抽出すれば人 間の食䊓とすることも可能である。フミノ酸分析の結 果, 原料によるアミノ酸パターンの相異は認められなか った。制限アミノ酸はメチオニンだが，全アミノ酸に対 する百分比では,フィッシュミールよりは少ないとはい え，他のどの高たんぱく飼料上りる大である。同様の比 较で,トリプトフェンは各種飼料中最大であり，その他 の必須フミノ酸はフィッシュミールを除いて同等あるい はそれ以上である。ペプシンーパンクレフチン消化試験の
結果, アルファルファ汁液の噴蓩畭燥物の生物価はラク トアルブミン, 牛乳と同等で, カゼイン, 牛肉, イース ト，大豆上りは高い。ビタミンについては， $\beta$ カロチン は他の飼料に比して多量に存在し, チアミンは綿実粕と 同じ程度でありその他の飼料よりは多量に含まれてい る。ビタミン保持の見地からす噴霧乾燥は有効な手段と いえる。毒性物質のサポニン，フェノール化合物は可溶 性のものばかりとは限らないので, 汁液中に多量に存在 するおそれはない。(表 4)

Leaf Protein Concentrate Prepared by Spray. Drying.

by Hartman, G.H. Jr., Akeson, W.R., Stahmann M. A.: J. Agr. Food Chem., 15, 74 79 (1967)

(劒持) 